\title{
Migration as a factor of cultural and sub-cultural diversity- case of Korca city
}

\author{
Denisa Titili, \\ $\mathrm{PhD}$ candidate \\ Department of Social Sciences \\ Faculty of Natural and Human Sciences \\ University "Fan S. Noli" Korça, Albania \\ xhafkadenisa@yahoo.com
}

\begin{abstract}
:
Sociological studies pay special attention to the mechanisms of cultural change and development, as well as the main factors that determine such dynamics. Zyhdi Dervishi (2011) considers cultural diffusion as one of the most influential factors of cultural development. Referring to the sociological literature consulted for this study, it is founded that Albanian culture is described as a mosaic of diverse subcultures, which differ greatly from one another. This sub-cultural diversity is evidenced in all components of cultural system; the docks, customs, manner of speaking, clothing, lifestyle, religious and pagan rituals and ceremonials, art, music, poetry, norms, values, symbols, elements of material culture etc. There are a number of factors that have contributed significantly in shaping the features of Albanian culture and its sub-cultural diversity. One of these factors is migration. It is noticed that migratory movements affect social and cultural development; major changes occur in family relationships, lifestyle, tendency for new cultural values acquisition, etc. This is more evident in rural- urban migration, as well as in international migration phenomenon. New economic resources, new working devices, system of social relationship in host society comprise an important source in transforming people's lives. Over the past twenty years Albanian society has experienced a number of economic, social and cultural changes, caused especially by increasing flows of internal and international migrants. Significant cultural changes are evidenced in social and cultural environment of Korça city, which is characterized by the phenomenon of massive displacement of population from rural areas to the city, as well as migration phenomenon in Greece. Taking into consideration the complexity of migration phenomenon and the consequences it brings in cultural plan, we intend to highlight and examine elements of sub-cultural diversity in Korça city, caused by internal and international migration. This paper draws on a research in Korça city, located in southeast of Albania, $35 \mathrm{~km}$ to the Greek border, which reflects a cultural environment where are intertwined trends of the cultural change, caused by migration from rural areas within the city and emigration process to neighboring Greece. In-depth interviews and observation will be used for data collection. Combined analysis of qualitative and quantitative methods will be used for data processing. This enables making comparisons and identifying problems. This paper aims to identify and analyze the impact of migration in sub-cultural diversity and aspects of the coexistence between rural subculture, urban subculture and the one of people having migration experience to Greece.
\end{abstract}

Key words: internal and international migration, cultural diffusion, subculture, cultural values

\section{Introduction:}

Cultural diversity is closely related to the act of displacement and movement of people from one place to another and adapting to new social and cultural environment. Migratory movements in the contemporary world are extremely diverse. There are three general classifications for migratory movements: (a) internal and international migration (that is the focus of our study), (b) voluntary and forced movements and (c) temporary and permanent migration ( King R, 2007, p. 7). These are very useful classifications to create a conceptual map of human movements.

Migration phenomenon has widely affected the Albanian society and Korça region in particular. From 1990 until 2005, over 1 million Albanians migrated abroad and about 400,000 others are thought to have moved within the country (INSTAT 2001). Internal and international migration is one of the most dynamic and specifying occurrence of Albanian society from 1990.

Due to these changes, developments in Albania and in Korça region after 1990 are characterized by profound changes in the cultural field. Given these changes, we want to study the case of Korça city, which represents a as a cultural environment where are intertwined trends of the cultural change, caused by migration from rural areas within the city and emigration process to neighboring Greece and because of the coexistence of these changes in a city with sustainable cultural trend. 
It should be noted that it is interesting to explore areas such as Korça region, which has an established tradition of migrating, largely renewed after 1990, as a result of political, economic, social and cultural changes that occurred in Albania.

This study documents the phenomenon of migration in the local context of Korça city. The study, based on original data, aims to highlight the impact of migration to sub-cultural diversity and to identify sub-cultural features caused by the phenomenon of massive displacement of population from rural areas to the city, as well as the phenomenon of migration in Greece. Internal and international out migration are analysed as interlinked processes, to point out the influence they have on each other, which requires an integrated approach.

People moved from rural areas and those who left Korça city and migrated to Greece constitute the empirical basis of the study. Observation and in-depth interviews with them enabled a holistic knowledge and understanding of the phenomenon of integration and coexistence of residents with different sub-cultural backgrounds. Their migratory experiences, adaptation to new social and cultural environment, the challenges of social integration in the host society, combined with the preservation of the sub-cultural traits, have given Korça city the physiognomy of a sub-cultural diverse environment, which should be recognized in all its totality.

The aim of this paper is to point out how migratory processes lead to sub-cultural diversity. The question that naturally arises in this context is: in terms of such diversity, to what extent are integrated members of different subcultures and what are the problems associated with coexistence between members of different subcultures?

The study aims to analyse and explain an important sociological phenomenon; the displacement of people in the developed world looking for a better way of living and the consequences of this shift in cultural terms (shift includes both internal ruralurban migration and international one).

\section{Research Methodology}

The purpose of this study is to analyze the impact of migration on sub-cultural diversity. The study was extended in Korça city, which reflects a cultural environment where are intertwined trends of cultural change, caused by migration from rural areas within the city and migration process to neighboring Greece. Interviews and observation were used to data collection. 50 in-depth interviews were realized; 20 interviews with people moved from rural areas to Korça city, 30 interviews with seasonal migrant to Greece and migrants who have been returned to Korça city after a long migration experience to Greece. 20 of the interviewees were men and 30 were women. The interviewees represent a variety of socio-economic status, education level and migration experiences. The selection of the interviewees was made possible thanks to "snowball" method.

\section{The study realized these objectives:}

First, it allowed to identify the subcultural features of people moved from rural to urban areas, citizens of Korça and migrants to Greece.

\section{Second, it provided sufficient detail of information on impact of migration on cultural diversity}

Third, it allowed to highlight aspects of coexistence and intergration of people from differente subcultural backgrounds and to analyse the problems and difficulties associated to this coexistence.

Most empirical studies on internal and international migration are performed from the perspective of the country of origin. This paper provides a new viewpoint to study the impact of migration to sub-cultural diversity from the perspective of the country of origin and the one of destination, taken together, as Korça city represents a social environment where coexist residents come from rural areas, citizens of Korça and people with migratory experience to neighboring Greece, each with specific sub-cultural features and characteristics. This interlacing in sub-cultural level constitutes the main focus of this study.

\section{Albanian culture- A mosaic of subcultures}

It is necessary to present a brief overview of the uniqueness of albanian culture in general in order to understand the impact of migration on sub-cultural diversity in local level. Albanian culture is characterized by a high diversity of subcultures, representing a diversified subculture mosaic (Fuga A, \& Dervishi Z, 2010, p. 215). 
A map of the Albanian culture divided into subcultures could be made on the basis of linguistic differences, as a result of the action of many factors. Map of Albanian culture will generally resemble the dialectology map of Albanian language (Bobi G, 1997, p.77).

There is a number of factors that have contributed significantly in shaping the features of Albanian culture and its subcultural diversity. Some of the determining factors mentioned in differente literatures are:

- Albania's geographic position between East and West, as a result of which albanian culture contains Western and Eastern cultural elements

\section{Diffusion trends between Balkans}

Balkan people have experienced intensively intercultural diffusion (Dervishi Z, 2011, p.47). Common historical destiny of these people, geographical proximity, contacts between them, migration phenomenon etc, have resulted in diffusing and spreading a number of cultural features and elements between Balkans.

- Linguistic diversity (dialectal and sub-dialectal differences, and regional dialects)

- Religious diversity; Among Albanians religious diversity is an important factor which "shapes" subcultures or reinforces the original features of existing subcultures (Dervishi Z, 2013, p.95).

- Migration; since 1990 of internal and international migration is one of the most specifying phenomena of Albanian society, bringing significant economic, political, demographic, social and cultural changes.

Subcultural diversity in Albanian environment is a direct result of the impact of migration. Geographical position and historical circumstances led Albanians to be exposed to intensive social and cultural contacts which resulted in maintenance and conservation, loss and replacement, reconstruction continuously the features of Albanian culture (Bobi G, 1997, p.21).

All these factors gave Albanian culture its special physiognomy. Part of this subcultural mosaic is the subculture of Korca city, which is the focus of our study.

Migration and cultural diversity

Studies show that migration of people from rural to urban and suburban areas, as well as international out migration cause significant consequences in their lives in terms of education, employment, family relationships, lifestyle in general (Rye, 2011; King \& Skeldon, 2010; Santoro, 2011; Vullntari, 2012). Migrants bring a set of cultural resources in the new country of destination. Migrants are exposed to the host society culture, as well as to the culture of their group or society. They create mechanisms for social and cultural integration in the destination country, creating sub-cultural oasis.

During the last decade Albania has undergone e series of deep political, economic, social and cultural reforms which have affected in determining the typology of Albanian society; such as migratory movements. Julie Vullnetari (2012) uses the expression "Albania on move" to define the typology of Albanian society. Young people are the main actors of these complex movements (Fuga A \& Dervishi Z, 2010, p. 15).

Understanding the phenomenon of migration as a source of sub-cultural diversity in Albanian society needs an integrated approach. Internal and international migration are parts of the same system; this is particularly evident in case of Albanian migration, most of Albanians were involved in both types of migration, both internal and international. in most cases, remittances from migrants abroad have motivated and facilitated internal migration. Studies show that internal migration affects out international migration and vice versa (Pryor, 1981; Skeldon, 2006; Vullnetari, 2012). Based on this information we argue that the study of internal and international migration, as a phenomenon of Albanian society after 1990 should be studied by a common analytical context. Only an integrated approach that sees internal and international migration interlinked enables a full understanding of the diversity of migratory experiences and the complexity of sub-cultural interactions.

This paper is based on Pryor's approach (1981) about the interaction between internal and international migration.

\section{Korça city}

Korça is the most important regional pole of the south-east of Albania. It is the main city of the Prefecture of Korça. It is located along one of the most important trade routes linking Albania with Balkans and Europe, through Greece and Macedonia. Founded in thirteenth century Korça was historically an important market town, which by the mid- nineteenth 
century had around 1,000 commercial shops (Vullnetari J, 2012, p. 27). Korça city is the second most important destination (besides Tirana) for migrants from rural areas of southeast part of the country.

Korça city lies in the southeastern part of Albania and is one of the most popular centers of this part. Korça is 181 kilometers far away from the capital. It has a favorable geographic position as it is located in trade routes linking Albania with Macedonia $(47 \mathrm{~km})$ and Greece $(35 \mathrm{~km})$. Korça city is divided between the rich history inherited and transformation into a modern urban area.

Korça represents an urban center where tradition is preserved alongside inserting innovations and modern developments, with traditional culture and contemporary educational development, with an advanced university centre, characterized by an ongoing harmony between communities; an urban environment which rises and develops in accordance with national strategy and global development trends. The geographical position of Korça city has helped the movement of population, business development, because Korça represents an economic and communicative join with Thessaloniki (Greece) and Tirana (Nikaj. I, 2011, p.126).

Local statistical indicators show a large number of people moved from villages around to Korça city, which has resulted in significant changes in structural composition of its population, lifestyle, as well as in social interaction between individuals of different sub-cultural groups.

Since 1990 the number of people in Korça city has undergone significant changes as a result of movements of people not only from the surrounding villages to the city, but also from migrating to Greece. It is estimated that migrants from Korça to Greece are about 23000. in 2010 about 280 migrants returned from Greece to Korça city buying new apartments. This has led to the expansion of the city by creating new residential neighborhoods which are characterized by new constructions that reflect cultural influences of host societies.

Table 1 and 2 introduces population movements in Korça city over years.

\section{A brief review of the survey}

Due to empirical data collected through interviews with people moved from village to Korça city and those with migration experience to Greece it is founded that there is a number of indicators which show the degree of social and cultural integration of migrants in the host society, as well as a variety of cultural elements carried from the country of origin, which indicate the existence of a diversified cultural environment. Migrants from rural areas have been distributed throughout the city, besides some of them who are located in the south-east or in the suburb of the city. This spatial distribution facilitates their integration, but also overshadows cultural features of the city, especially its historical part.

A characteristic feature of rural areas is a socio-cultural system based on reciprocal relations between the social and cultural units such as family, brotherhood, tribe, village etc, which still remains even after they move to urban area. This is more evident when it comes to neighborhood. Neighborhood preferences of people moved from village are for others come from the same village as they come or from other villages. This is confirmed by women interviewed who have moved from rural areas to the city. They claim that they have better relationships with other women come from village rather than city women. These relationships are associated with family visits, morning coffees at each other's homes. Such practices are typical for rural environment, unlike urban culture characterized by extreme individualism.

Internal migration in Albania is often held in form of chain migration. Therefore, social networks, kin interaction, financial and socio-psychological support take a special importance in discussing the process of integration of migrants in the new urban environment. Chain migration leads to creation of specific socio-cultural groups in urban environments. While the number of migrants in the urban area grows, they create their own communities, with their own values and lifestyles often making the host society feel like a stranger.

Links with rural environment are an indicator for the preservation of values and practices of rural subcultures. These are more evident in family relationships, in gender and generation relations. Duration of stay in urban space plays an important role. Most of them claim that they feel part of urban life in terms of employment, education, social participation, dressing style, communication, way of behaving etc. While people moved from the village to Korça city after migrating to Greece represent a sub-cultural group where cultural elements of rural environment are intertwined with practices and models derived from Greek culture. Sub-cultural diversity rate also depends on the degree of their integration into Greek society and culture.

A first approach to measure cultural integration consists in collecting empirical data about the actual behavior of migrants, to evaluate how it differs from that of the dominant group members. Typical indicators include language spoken at home 
(the case of migrants abroad), religious practices, fertility, educational achievement, gender relations, social participation, marriages (marriages between them), divorce, etc.

Albanian migrants to Greece are well adapted to the new way of life in Greek society, they communicate easily with natives, frequent the same places as locals, dress like them, listen to Greek music, have acquired practices and behavioral patterns which make them too similar to the social environment where they live. Such elements are easily obvious, especially when they return to their home country, carrying with them these new practices acquired from the coexistence with Greek culture. But when it comes to mentality, cultural values which characterize psycho- cultural shaping of Albanians the differences are quite inconsiderable. Cultural values and attitudes related to marital and family relations, relations between generations, attitudes towards sexuality etc, clearly reflect Albanian cultural environment. These cultural models, are not only saved between Albanians migrated to Greece (as an indicator of Albanian cultural identity), but they are reinforced and emphasized especially after they return home. This is primarily evident among people moved from rural areas, who have experienced migration in Greece, as well as between individuals belonging to the old generation.

However it is worth mentioning that staying for a long time in Greek cultural environment and efforts for social inclusion and integration have influenced in modifying many cultural attitudes in terms of cultural emancipation of Albanian migrants. These are more evident among youths. Social remittances play an important role. According to Levitt (1998) social remittances represent the totality of ideas, behaviors, social capital transmitted from the host country community to the country of origin.

The impact of social remittances is more obvious in the architecture and interior design of the apartments. Also migrants bring with them new skills and technologies, used to open new businesses such as fast-food-shops, beauty salons, carpentry, etc. Migration promotes new ways of living and family relationships. Experience shows that migration can provide new opportunities to improve women's lives and change oppressive gender relations - even displacement as a result of conflict can lead to shifts in gendered roles and responsibilities to women's benefit.

Migration brings new perspectives and enriches cultural diversity.

\section{References:}

Bobi, G. (1997). Paradoks kulturor, Vepra 2, Dukagjini. Pejë

[2] Bottomley, G. (2009). From another place- Migration and policies of culture, Cambridge

[3] University Press, New York

[4] Buletini Statistikor Korçë 2008

[5] Çaro, E. (2011). From the village to the city - Adjustment process of internal migrants

[6] in Albania, Rozenberg Publishers, Amsterdam

[7] Danopoulos C. Andrew., \& Danopoulos P. Constantine. Albanian Migration into

[8] Greece: The Economic, Sociological and Security Implications, MUSE

[9] Project, 100-114

[10] Dervishi, Z. (2013). Nëpër degëzime të kulturës shqiptare, Shtëpia Botuese EMAL, Tiranë

[11] Fuga, A., \& Dervishi, Z. (2010). Ndërmjet fshatit dhe qytetërimit global, Botimet Dudaj,

[12] Tiranë

[13] Hatziprokopiou, P. (2003) Albanian immigrants in Thessaloniki, Greece: Processes of

[14] economic and social incorporation, Journal of Ethnic and Migration Studies, Vol.29 No. 6 1033-1057

[15] Hatziprokopiou, P. (2004). Balkan immigrants in the Greek city of Thessaloniki: Lokal processes

[16] of incorporation in an international perspective, Europian Urban and Regional Studies,11(4) 321-338

[17] INSTAT 2001, Popullsia e Shqipërisë, Prefektura e Korçës

[18] Levitt, P. (1998). Social remittances: Migration driven local-level forms of cultural diffusion,

[19] International Migration Review 32(4): 926-948

[20] King, R., \& Vullnetari, J. (2009). The intersections of gender and generations in Albanian

[21] migration, remittances and transnational care, Journal Compilation, Swedish

[22] Society for Anthropology and Geography, Vol. 91, 19-38

[23] Nikaj, I.( 2011) "Ndryshime individuale dhe shoqërore përmes trajektoreve 
[24] biografike" tek Lente Sociologjike, Vëllimi 1, Nr.1

[25] Özdemir, E. (2003). The effects of rural-to-urban migration on the status of women in

[26] Turkey, Turkish Journal of Population Studies, 25, 69-96

[27] Pryor, R. J. (1981). "Integrating international and internal migration theories" in M. M. Kritz, C.

[28] B. Keely \& S. M. Tomasi, Global Trends Migration: Theory and research of

[29] international population movement, 110-129. New York: Centre for Migration Studies

[30] Sara, R. C., \& Abigail, C. S. (2001). Migration and Cultural Change: A Role for Gender

[31] and Social Networks, Journal of International Women's Studies,Vol.2 54-77

[32] Sowell, Th. (1996). Migrations and cultures- A World View, Published by Basic Books,

[33] New York

[34] Titili, D., \& Nikaj, I. (2012). Migration and culture: The impact of internal and

[35] international migration on women- men relationship, Journal of Educational

[36] and Social Research, Vol. 2 No.5 251-257

[37] Vullnetari, J. (2007) Albanian Migration and Development: State of the Art Review,

[38] IMISCOE Working Paper, No.18.

[39] Vullnetari, J. (2012). Albania on move: Links between Internal and International Migration,

[40] Amsterdam University Press

\section{Tables}

$\begin{array}{ll}\text { Table 1- The number of residents in Korça city from } 1990 \text { to } 2009 \\ \text { Year } & \text { Number of people } \\ 1990 & 65000 \\ 1995 & 73499 \\ 2000 & 80772 \\ 2005 & 85590 \\ 2009 & 86596\end{array}$

Table 2- The number of people moved from rural areas to Korça city and the ones left Korça city

$\begin{array}{lll}\text { Year } & \text { People moved from village to the city } & \text { People gone away from the city } \\ 2005 & 2456 & 1163 \\ 2008 & 716 & 614 \\ 2009 & 925 & 572\end{array}$

Source: Statistical office in Prefecture of Korça 